\title{
At 50 years of the description of acute respiratory distress syndrome
}

\author{
Raúl Carrillo-Esper ${ }^{1}$, Gilberto Felipe Vázquez-De Anda², Cynthia Ivonne Mejía-Pérez², \\ María Guadalupe Delaye-Aguilar ${ }^{3}$, Ana Ivonne Pérez-Castañeda ${ }^{3}$, Jesús Carlos Briones-Garduño ${ }^{4}$ and \\ Manuel Antonio Díaz de León-Ponce ${ }^{1}$ \\ ${ }^{1}$ Academia Nacional de Medicina de México; ${ }^{2}$ Instituto Mexicano del Seguro Social, Centro Médico Nacional Siglo XXI, Specialty Hospital; ${ }^{3}$ Center \\ of Research in Medical Sciences, Universidad Autónoma del Estado de México; ${ }^{4}$ Secretaría de Salud, Hospital General de México, Department of \\ Obstetrics and Gynecology, Ciudad de México, Mexico
}

\begin{abstract}
In 1967, Ashbaugh et al. published in the Lancet the description of a new entity, for which they coined the name "adult respiratory distress syndrome". On that article, they thoroughly described 12 patients who had respiratory distress with bilateral pulmonary infiltrates and oxygen therapy-refractory hypoxemia. For its management, emphasis was made on the importance of intubation and mechanical ventilation with positive end-expiratory pressure. At 50 years of its first publication, great advances on the knowledge of this condition have been achieved, which has influenced on patient management and survival. To celebrate this $50^{\text {th }}$ anniversary, the National Academy of Medicine of Mexico organized a symposium with the purpose to spread the knowledge about this condition, recognize the researchers who made the original description and those who over the course of 50 years of history have contributed to its better understanding. The symposium addressed the topics of lung-kidney interaction, molecular bases of the disease and therapeutic advances.
\end{abstract}

KEY WORDS: Acute respiratory distress syndrome. Mechanical ventilation. Hypoxemia. Positive end-expiratory pressure.

\section{Acute respiratory distress syndrome}

\author{
Raúl Carrillo-Esper
}

\section{Introduction}

On August 12, 1967, the renowned journal The Lancet published an article entitled "Acute Respiratory Distress in Adults", signed by doctors David G. Ashbaugh, Boyd Bigelow, Thomas L. Petty and Bernard Levine. Doctor Thomas L. Petty, a distinguished pulmonologist, was a key piece to the publication. In that work, the authors described a previously wrongly conceptualized entity, defined it and established diagnostic criteria and the bases of treatment; in a few words, they described a new disease which they generically named "respiratory distress syndrome in adults"
(RDSA) and clearly differentiated it from pulmonary edema secondary to heart failure; currently, this entity is referred to as acute respiratory distress syndrome (ARDS) $^{1}$ (Fig. 1 and 2).

RDSA description was based on the characterization of a series of 12 patients with acute respiratory distress, oxygen therapy-resistant cyanosis, decreased pulmonary distensibility and diffuse pulmonary infiltrates on chest $\mathrm{X}$-ray. The histopathologic substrate they described was similar to that observed in the lungs of children with respiratory failure, to congestive atelectasis and to lung post-reperfusion lung injury. Microscopically, hemorrhage, congestion,
Correspondence: Raúl Carrillo-Esper

E-mail: revistacma@comexane.org
Date of reception: 30-11-2017

Date of acceptance: 16-01-2018

DOI://dx.doi.org/10.24875/GMM.M18000139
Gac Med Mex. 2018;154:188-205

Contents available at PubMed www.gacetamedicademexico.com 
ACUTE RESPIRATORY DISTRESS IN ADULTS

David G. Ashraugh

M.D. Ohio State

ASSISTANT PROFESSOR OF SURGERY

D. BOYD Bigelow

M.D. Colorado

ASSISTANT IN MEDICINE AND AMERICAN THORACIC SOCIETY-NATIONAI TUBERCULOSIS ASSOCIATION FELLOW IN PULMONARY DISEASE

Thomas L. Petty M.D. Colorado

ASSISTANT PROFESSOR OF MEDICINE

BERNARD E. LEVINE M.D. Michigan

AMERTAN THORACIC SOCIETY-NATIONAL TUBERCULOSIS ASSOCIATION FELLOW IN PULMONARY DISEASE*

From the Departments of Surgery and Medicine, University of Colorado Medical Center, Denver, Colorado, U.S.A.

Figure 1. Cover of the original article "Acute Respiratory Distress Syndrome in Adults", published in The Lancet on August 12, 1967.

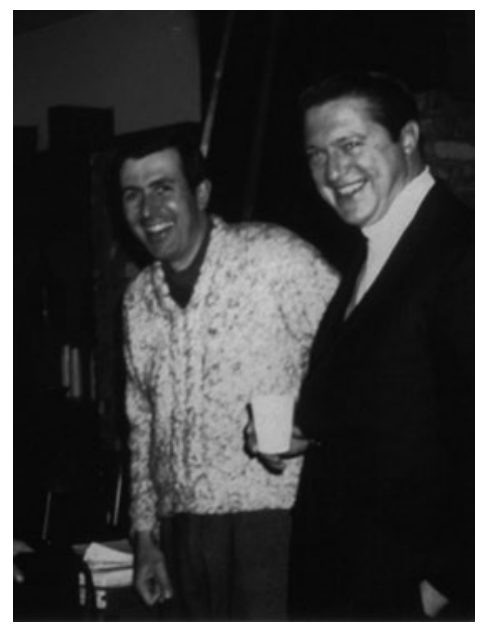

Figure 2. The pioneers in the description and definition of acute respiratory distress syndrome, doctors Thomas L. Petty (dark coat) and David G. Ashbaugh (white sweater).

microatelectasis, diffuse alveolar damage and hyaline membranes was observed. Mortality was $58 \%$, with better survival opportunity in patients managed with mechanical ventilation and positive end-expiratory pressure PEEP.

At 50 years of the description of this entity, the outlook has radically changed: advances on the knowledge of its genetic, molecular and pathophysiological bases has enabled a better understanding of the disease clinical behavior, which has enabled the development of ventilatory and non-ventilatory strategies that are essential to improving survival.

\section{Epidemiology}

ARDS is a complex and heterogeneous disease. It is considered a public health problem owing to its elevated incidence, costs of care and sequels. Its epidemiological profile is changeable and variable, depending on the assessed region, on available resources for its diagnosis and treatment and on the setting where it occurs, either community-based or hospital-based. Something that is certain is the complexity of its epidemiological behavior, which was assessed by the LUNG-SAFE study, a multinational study that provided essential data to better understand ARDS and its behavior by regions. Global incidence is as variable as 3 to 80 per 100,000 population, with mortality ranging from 15 to $66 \%$. Such discordant figures depend on the assessed region and institution. ${ }^{2,3}$

\section{Definition}

ARDS is a type of acute respiratory insufficiency secondary to inflammation that results in increased endothelial permeability and epithelial injury, which leads to fluid buildup in the interstitium and sacs, increased pulmonary shunting and standard oxygen therapy-refractory hypoxemia. Its understanding has to start with a definition based on constructs resulting from a complex substrate of genetic, molecular and cellular interactions that elicit a considerable number of reactions that can be clinically assessed, as well as with laboratory and imaging studies. The definition has varied since its description in 1967, with different modifications being carried out as a result of the work of several groups until arriving to the Berlin Definition, which is currently valid. In this sense, several moments can be highlighted in the evolution of the defining criteria:

a) 1967: Ashbaugh et al. highlighted dyspnea, tachypnea, oxygen therapy-resistant cyanosis, decreased pulmonary distensibility, diffuse pulmonary infiltrates on chest X-ray, atelectasis, vascular congestion, hemorrhage, pulmonary edema and hyaline membranes.

b) 1988: Murray et al. ${ }^{4}$ established a scale that includes oxygenation, PEEP levels, respiratory system distensibility and pulmonary infiltrates extension, assessed by quadrants on chest $\mathrm{X}$-ray.

c) 1994: Bernard et al., ${ }^{5}$ based on the American-European Consensus Conference, established a definition based on three criteria that included chest $\mathrm{X}$-ray, oxygenation index based on the $\mathrm{PaO}_{2} / \mathrm{FiO}_{2}$ ratio and exclusion of heart failure as the cause of pulmonary congestion and edema, out of which the following criteria were derived:

- Acute appearance of pulmonary infiltrates on chest X-ray 
Table 1. The Berlin Definition

\section{Etiology \\ Respiratory failure not completely explained by heart failure or fluid overload. \\ Objective evaluation is required (e.g., echocardiogram) in order to rule out hydrostatic edema, if risk factors are not identified.}

\section{Time of onset}

Onset within 1 week of a known clinical triggering factor or new respiratory symptoms that worsen

\section{Chest X-ray or computed axial tomography}

Bilateral infiltrates, not completely explained by effusion, lobar or pulmonary collapse or nodules.

\section{Oxygenation alteration \\ If altitude is $>1000 \mathrm{~m}$, correct $\mathrm{PaO}_{2} / \mathrm{FiO}_{2} \times$ (barometric pressure $[\mathrm{PB} / 760])$ \\ - Mild ARDS: $200<\mathrm{PaO}_{2} / \mathrm{FiO}_{2} \leq 300$ with PEEP or CPAP $\geq 5 \mathrm{~cm} \mathrm{H}_{2} \mathrm{O}$ - Moderate ARDS: $100<\mathrm{PaO}_{2} / \mathrm{FiO}_{2} \leq 200$ with PEEP $\geq 5 \mathrm{~cm} \mathrm{H}_{2} \mathrm{O}$ - Severe ARDS: $\mathrm{PaO}_{2} / \mathrm{FiO}_{2} \leq 100$ with $\mathrm{PEEP} \geq 5 \mathrm{~cm} \mathrm{H}_{2} \mathrm{O}$}

$\mathrm{PaO}_{2}$, arterial pressure of oxygen; $\mathrm{FiO}_{2}$, fraction of inspired oxygen; PEEP, positive end expiratory pressure; CPAP, continuous positive airway pressure; ARDS, acute respiratory distress syndrome.

- Pulmonary artery wedge pressure $<19 \mathrm{mmHg}$ or absence of left atrium hypertension

- $\mathrm{PaO}_{2} / \mathrm{FiO}_{2}$ ratio $<300 \mathrm{mmHg}$, with ARDS criterion with a $\mathrm{PaO}_{2} / \mathrm{FiO}_{2}$ ratio $<200 \mathrm{mmHg}$

d) Berlin Definition. ${ }^{6}$ Since its publication in 2012, it is the definition used to clinically define the disease. With regard to previous definitions, it eliminates the term acute pulmonary injury and the pulmonary capillary pressure criterion, in addition to introducing ventilation adjustments at PEEP $>5$. Some concepts regarded as classical in ARDS were eliminated in this definition, such as infiltrate extension, respiratory system distensibility, PEEP $>10 \mathrm{~cm} \mathrm{H}_{2} \mathrm{O}$ and corrected exhaled minute volume $(>10 \mathrm{~L} / \mathrm{m})$. In spite of being a more consistent definition, based on a large sample and on scientific evidence, it will surely be improved in the future (Table 1).

The authors emphasize that cardiogenic pulmonary edema and other causes of respiratory insufficiency and pulmonary infiltrates should be ruled out and comply with the following criteria:

- Acute onset within the first week of triggering event occurrence.

- Bilateral pulmonary infiltrates on chest X-ray or computed axial tomography, not explained by pleural effusion, atelectasis or pulmonary nodules.

- Infiltrates not explained by heart failure or fluid overload. Echocardiogram may be required to assess cardiac function.
- Oxygenation deterioration, defined by the $\mathrm{PaO}_{2} / \mathrm{FiO}_{2}$ ratio (proportion between oxygen arterial pressure and the fraction of inspired oxygen) or by the $\mathrm{SaO}_{2} /$ $\mathrm{FiO}_{2}$ ratio (proportion between peripheral pulse oximetry and the fraction of inspired oxygen).

- The degree of hypoxemia defines associated seriousness and mortality.

\section{Advances and contributions}

In 50 years, significant advances have been achieved in the knowledge of ARDS regarding its molecular biology, pathophysiology, imaging techniques for its assessment, clinical scenarios, evolution patterns, hemodynamic behavior, inter-organ communication, outcomes and pharmacological and ventilatory treatment.

In the syndrome initial description, the authors pointed at the presence of pulmonary congestion, atelectasis and diffuse alveolar damage accompanied by alveolar edema and hemorrhage as characteristics of the disease. Building upon this initial description, and based on animal and clinical models, the interactions unleashed by a triggering factor to activate an intricate molecular and cellular signaling network that mounts an intense pulmonary and systemic inflammatory reaction have been understood. This reaction is the basis of alveolar injury at the endothelial, epithelial and surfactant level, with the latter being ARDS essential substrate, which is tightly correlated with the content of interstitial and alveolar water, clinical and mechanical behavior, the different evolutionary phases and the biomarkers used for diagnosis and follow-up. Deep hypoxemia that is resistant to fraction of inspired oxygen increase, secondary to alveolar collapse and intrapulmonary shunting increase $(\mathrm{Q} / \mathrm{Qt})$, is essential to clinical and pathophysiological evolution. ${ }^{7,8}$

One of the great advances in the knowledge of ARDS is the "baby lung" concept developed by Gattinoni's group based on studies of computed axial tomography and pulmonary mechanics. It represents the percentage of functional and anatomically healthy lung of the patient with ARDS. It depends on the severity of the injury and determines the respiratory system distensibility, $\mathrm{CO}_{2}$ elimination and oxygenation. It has a different behavior to that of the fraction of diseased lung, but is at risk of inflammation and dysfunction, especially if there is volume overload, if an inadequate ventilatory strategy is selected or if the triggering factor is not controlled. It is important mentioning that ARDS is not a homogeneous but a 


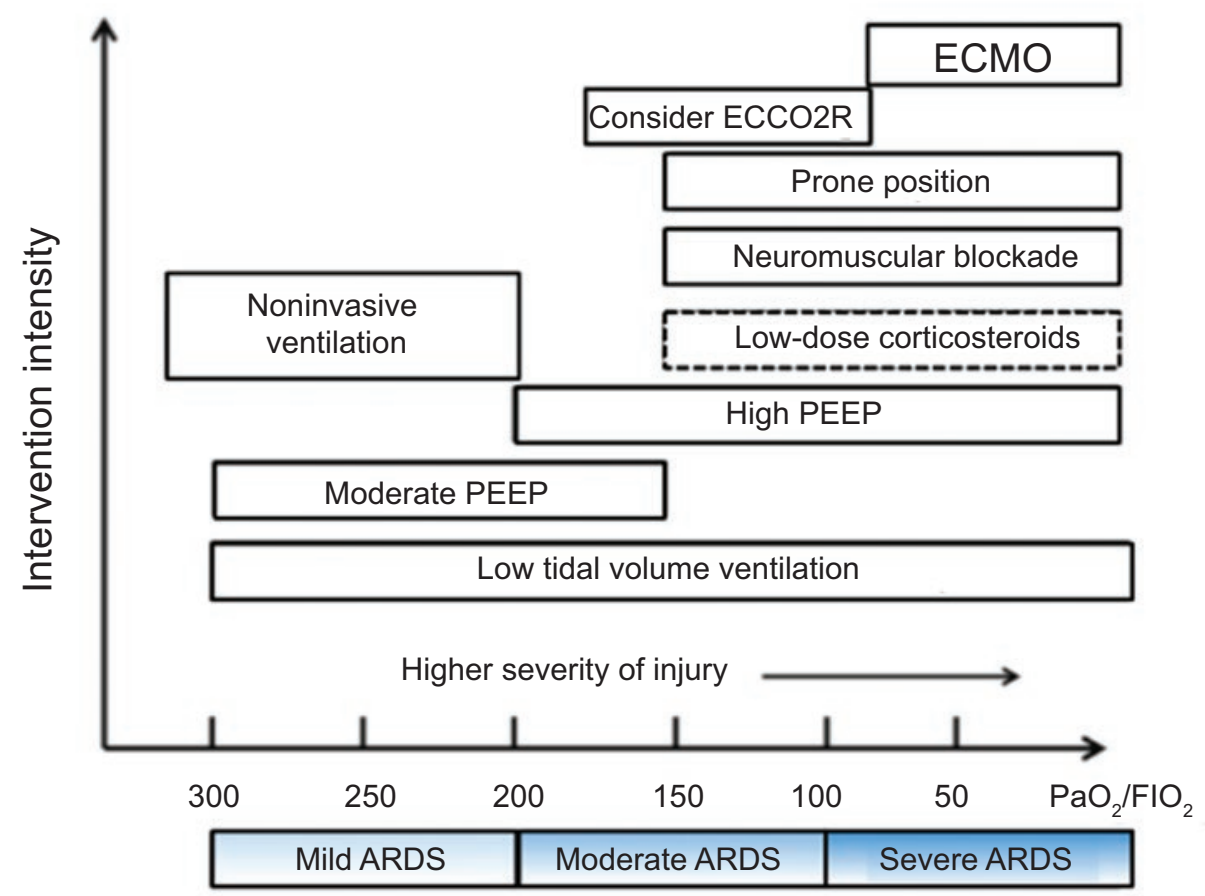

Figure 3. Management strategies according to acute respiratory distress syndrome (ARDS) severity. PEEP, positive end expiration pressure; $E \mathrm{CCO}_{2} \mathrm{R}$, extracorporeal $\mathrm{CO}_{2}$ removal; ECMO; extracorporeal membrane oxygenation.

heterogeneous injury and predominantly basal, with three alveolar segmental areas, condensation, collapse and opening being delimited. The "baby lung" concept determined the knowledge and development of the essential management strategies, with ventilation with low tidal volumes, lung protection, alveolar opening and the prone position, among others, standing out. ${ }^{9,10-12}$

\section{Mechanical ventilation}

To this moment, no drug has been effective to prevent or treat ARDS, although mechanical ventilation has become the cornerstone of treatment. Based on the knowledge of its pathophysiology and molecular biology, different ventilation modes have been developed according to the pulmonary cellular and mechanical behavior; especially, advances have been made in the concept of injury, which can result in inadequate selection of the ventilation mode and that is related to excessive transpulmonary pressure or to either positive or negative pleural pressure significant modifications, which impact by inducing more inflammation, alveolar damage and hemodynamic instability. Ventilation monitoring and knowledge of the changes presented by pulmonary and thoracic mechanics were key to the development of the different ventilation modes and, especially, to their implementation based on a personalized protocol..$^{13-16}$

According to scientific evidence, mechanical ventilation with low tidal volumes ( 6 to $8 \mathrm{~mL} / \mathrm{kg}$ ), maintaining a plateau pressure $<30 \mathrm{~cm} \mathrm{H}_{2} \mathrm{O}$ (especially at $28 \mathrm{~cm} \mathrm{H}_{2} \mathrm{O}$ ) and adequate PEEP titration and inspiratory flow decrease, together with a right ventricle protecting strategy, have been established to be the best option for survival, especially because they reduce the risk for developing ventilator-induced lung injury (VILI). Patients with ARDS mild forms can respond to non-invasive ventilation with CPAP or other ventilation modes, with bi-level ventilation, proportional assist ventilation and high oxygen flows standing out. In severe forms with standard ventilatory management-resistant hypoxemia, high-frequency oscillatory ventilation or extracorporeal membrane oxygenation can be implemented, together with other measures such as the prone position. ${ }^{17-20}$

Currently, new concepts related to mechanical ventilation, its potential deleterious effects and prognosis are being promoted. Among them, distension pressure and mechanical power, which establish mechanical ventilation safety limits and help for a ventilation strategy that ensures the least lung injury and the highest survival to be dynamically individualized, stand out (Figure 3). ${ }^{21-22}$ 
Together with mechanical ventilation, adjuvant measures have been implemented for the management of ARDS, such as the use of neuromuscular blockers at early phases, which have resulted in survival improvements, and steroids and prostacyclin in selected patients. Combination of an individualized ventilation strategy with goal-oriented management and maintenance of a neutral or negative water balance according to a conservative strategy is essential. Given that most pharmacological treatments have failed, new alternatives with potential impact on ARDS continue to be tried, including aspirin and stem cells. ${ }^{23-29}$
Over the last years, ARDS has been found to leave important sequels in patients who survive, which limit their quality of life and increase the costs of care; among them, neuropathy, myopathy, sarcopenia, muscle contractures, neurocognitive impairment and post-traumatic stress syndrome, which can persist for up to 5 years after diagnosis in spite of treatment and rehabilitation, are worth mentioning. For this reason, studies related to different scenarios in this sense, multidisciplinary management processes and information programs directed to patients and their families are being developed. ${ }^{30,31}$ 


\title{
Acute respiratory distress syndrome treatment
}

\author{
Gilberto Felipe Vázquez-De Anda, Cynthia Ivonne Mejía-Pérez, María Guadalupe Delaye-Aguilar, \\ Ana Ivonne Pérez-Castañeda
}

\section{Introduction}

On October 12, 1967, Ashbaugh, Bigelow, Petty and Levine described something that initially was to be named adult progressive respiratory distress syndrome (APRDS) in 12 adult patients. ${ }^{1}$ Classical description of the syndrome links signs of respiratory insufficiency under a single pathophysiological process similar to that observed in neonates with "hyaline membrane" disease, a variety of respiratory insufficiency observed in cases of alveolar surfactant deficiency. Fifty years ago, the description of what today is known as acute respiratory distress syndrome (ARDS) gathered in a single entity those events that had been described with multiple denominations such as "shock lung", "Na-gang lung", "wet lung" or respiratory distress due to fat embolism. These entities were characterized for being associated with direct or indirect injury to pulmonary tissue, which responded with an inflammatory process in alveolar and pulmonary capillary epithelium. ${ }^{1,32}$

ARDS point of impact and pathophysiological process basis is the alveolus (anatomo-functional unit of the lung), involving its three spaces: intra-alveolar, interstitial and vascular (endothelial), the manifestation of which is severe hypoxemia, pulmonary infiltrates and non-cardiovascular-origin pulmonary edema. ${ }^{32}$ This dynamic process alters alveolar properties in the air-fluid interface, enabling the entrance of fluids and proteins coming from the interstitial space into the alveolar space. This protein-rich edema alters alveolar surfactant properties, with its resulting inactivation. Inactivated surfactant increases alveolar surface tension, leading to alveolar collapse, promoting an increase in the number of shunts and decreased arterial oxygenation. ${ }^{32}$

In addition, arterial collapse increases the friction between adjacent alveoli, thus diffusing the inflammatory process, the evolution of which triggers fibrosis as an end-product, which causes loss of function in affected alveoli. Thus, the higher the number of involved alveoli, the greater the alveolar collapse and its consequences: hypoxemia, low pulmonary distensibility, increase in the number of intrapulmonary shunts, decreased functional capacity, atelectasis and non-cardiogenic pulmonary edema.

Over the course of 50 years, ARDS treatment has been focused on addressing each one of the pathophysiological process phases. In their original description, Ashbaugh et al. noted that mechanical ventilation is the most important therapeutic measure to counteract alveolar collapse effects by means of mechanical ventilation with positive pressure in order to recruit collapsed alveoli, as well as the use of positive end-expiratory pressure (PEEP), to prevent the collapse of functional alveolar units. ${ }^{1}$ Currently, ventilation by itself is known to be able to cause lung injury, even greater than that produced by the primary cause, and measures aimed at providing a protective ventilation should therefore be used. ${ }^{33}$ In addition, other therapeutic measures include decreasing or limiting the inflammatory process and maintaining the alveolar space free of fluid. ${ }^{1,32-34}$

\section{Measures to counteract the inflammatory process}

Lung injury can be directly (e.g. pneumonia) or indirectly induced (e.g., abdominal sepsis), which triggers an inflammatory process with the described consequences. Therefore, first of all, the cause that originated the lung injury should be treated. Early antibiotic initiation in cases of severe sepsis, drainage of abscesses or collections in cavities, hemodynamic stability, care of fractures in the cases of severe trauma are examples of primary measures in ARDS. ${ }^{35}$ The use of high end-inspiratory pulmonary volumes, combined with high airway pressure and low PEEP levels favor alveolar over-distension (with subsequent damage to the air-fluid interface) and the opening-collapse phenomenon (which causes alveolar wall direct injury by shear stress). Owing to this, it is imperative for protective mechanical ventilation to be promoted since the beginning by means of low plateau pressures $\left(<30 \mathrm{~cm} \mathrm{H}_{2} \mathrm{O}\right)$, as well as favoring a low tidal volume of $6 \mathrm{~mL} / \mathrm{kg}$ body weight (calculated as $50 \pm$ 0.91 [height in centimeters - 152.4] for males and 45.5 \pm 0.91 [height in centimeters - 152.4] for females), with cycling at low differential pressures (lower than 
$16 \mathrm{~cm} \mathrm{H}_{2} \mathrm{O}$ ) and PEEP appropriate levels (8 to $10 \mathrm{~cm}$ $\left.\mathrm{H}_{2} \mathrm{O}\right) .33,34,36$

The use of steroids to control the pulmonary inflammatory process and changes secondary to fibrosis has been documented since ARDS original description; however, their use is so far controverted and experts consider that steroids should be used only in special cases. ${ }^{33,37}$

Among other factors, severe supplementary oxygen-resistant hypoxemia observed in ARDS has been described to be related to hypoxia-induced vasoconstriction, to pulmonary hypertension and ventilation-perfusion ratio alterations. Owing to this, nitric oxide was thought to be able to be used as a therapeutic measure in ARDS owing to its properties as a vasodilator and anti-inflammatory agent. However, the results of recent clinical trials and meta-analyses failed to show an effect on mortality decrease at different levels of hypoxemia, in spite of improving oxygenation from 7 to $16 \%$. Neither has it demonstrated to reduce hospitalization costs or intensive care unit length of stay. Owing to the above, it should be rationally used and in specific cases. ${ }^{33,34,38}$

\section{Measures to decrease acute pulmonary edema of non-cardiovascular origin}

Acute pulmonary edema of non-cardiovascular origin was one of the main findings described by Ashbaugh et al. ${ }^{1}$ The authors described the bilateral infiltrates on chest X-ray. The origin of pulmonary edema is due to increased vascular permeability secondary to endothelial inflammatory process, to decreased fluid displacement by the alveolar interstitium and to the opening and collapse phenomenon, which promote a suction effect during alveolar collapse that favors the displacement of protein-rich fluid coming from the pulmonary capillary and interstitium towards the alveolar lumen. ${ }^{32}$

The use of albumin and neutral or negative balances has been promoted for more than 50 years. Sakr et al..$^{30}$ described the association between fluid balance and mortality in patients with acute lung injury-acute respiratory distress. In their study, they found that patients with acute respiratory distress were associated with more positive fluid balance at 96 hours than patients without acute lung injury. Furthermore, an association between positive fluid balance and higher mortality was established..$^{39}$ Martin et al..$^{40}$ treated acute lung injury (ALI)/ARDS patients with albumin and furosemide, comparing this treatment with standard treatment. The authors documented that, at third day of treatment, patients who received albumin and furosemide had higher $\mathrm{PaO}_{2} / \mathrm{FiO}_{2}$, higher total protein serum concentration and negative balances.

The Collaborative Group for the Treatment of ALI/ ARDS (ARDS Network), with participation of multiple hospitals in the United States, compared a group liberally treated with fluids and diuretics with a conservatively managed group by maintaining a neutral or negative hydric balance. The results showed that the conservative group received higher furosemide doses and obtained more negative balances from day 1 to 7 in comparison with the liberal group. In addition, less days on mechanical ventilation, less days on intensive care, less days of hospital stay and less days with organ dysfunction were observed in the conservative group. However, no differences were observed in mortality. ${ }^{41}$

\section{Measures aimed at counteracting alveolar collapse}

Mechanical ventilation has been the most effective measure to counteract alveolar collapse effects. However, it has been shown to be able to produce alveolar injure by itself when protective measures that prevent or limit mechanical ventilation-induced lung injury are not used. Protective ventilation is characterized for providing ventilation with high pulmonary volumes, cycling with low tidal volume, low inspiratory pressures, low differential pressures during cycling and adequate PEEP levels (Fig. 4). Brochard et al. ${ }^{42}$ carried out a comparative clinical trial at two tidal volume different doses: one group received protective ventilation with low tidal volume and the other received a high tidal volume, both groups with inspiratory pressure lower than $30 \mathrm{~cm} \mathrm{H}_{2} \mathrm{O}$. The results showed that there were no differences in mortality between the treated groups.

In the same period, Stewart et al. ${ }^{43}$ carried out a study with the purpose to determine the benefit of using tidal volumes of $7 \mathrm{~mL} / \mathrm{kg}$ versus $10 \mathrm{~mL} / \mathrm{kg}$ during mechanical ventilation. The results showed no mortality differences in both groups. As in the previously referred study, both groups were observed to maintain peak pressures lower than $30 \mathrm{~cm} \mathrm{H}_{2} \mathrm{O}$. Brower et al. ${ }^{44}$ conducted a comparative study where they administered two levels of tidal volume. The results showed no mortality differences. As in the previous studies, plateau pressures remained below $30 \mathrm{~cm} \mathrm{H}_{2} \mathrm{O}$. Amato et al. ${ }^{45}$ carried out a comparative study of patients with 


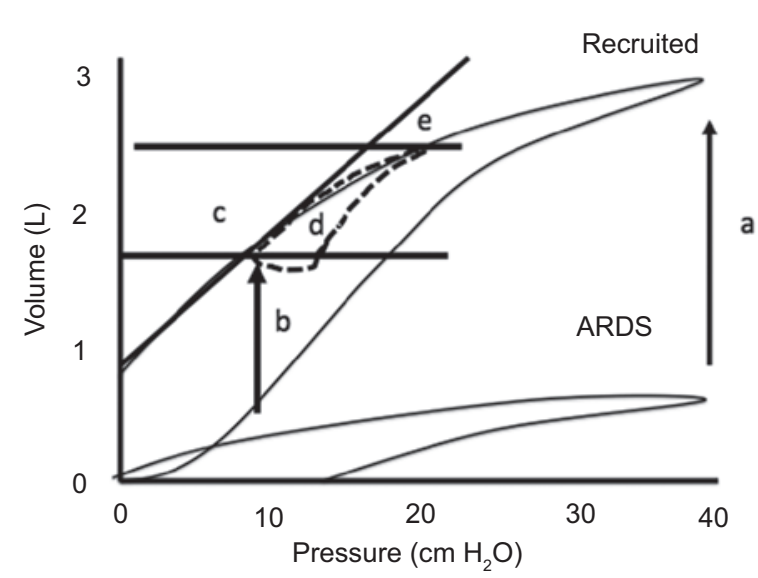

Figure 4. Pressure-volume curve, where the concept of protective ventilation during mechanical ventilation is shown. a) Recruitment maneuver. b) High end-expiratory lung volume. c) PEEP level to avoid end-expiratory alveolar collapse and lung volume loss. d) Cycling with low tidal volume at low differential pressures. e) Low plateau pressures to avoid end-inspiratory alveolar over-distension (for more details see text).

respiratory insufficiency: they exposed them to low tidal volumes, low plateau pressures and adequate PEEP levels after a recruitment maneuver. In this study, a significant difference in mortality was determined, with the group receiving protective ventilation having better survival. The ARDS Network ${ }^{46}$ conducted a multi-center clinical trial where two ventilation modes were compared. On group received protective ventilation versus standard ventilation, with a high tidal volume. In this study, ventilation with $12 \mathrm{~mL} / \mathrm{kg}$ tidal volume was documented to be associated with higher mortality in comparison with patients with protective ventilation, who received a tidal volume of $6 \mathrm{~mL} / \mathrm{kg}$. In addition, patients with protective ventilation were observed to maintain peak pressures lower than $30 \mathrm{~cm} \mathrm{H} \mathrm{H}_{2} \mathrm{O}$ : tidal volumes $\geq 12 \mathrm{~mL} / \mathrm{kg}$ were associated with higher mortality (Table 2). In a meta-analysis by Burns et al., ${ }^{47}$ a protective factor was determined in favor of mechanical ventilation protective measures characterized by low tidal volumes and low peak pressures.

In 1992, Lachman proposed pulmonary protection by means of collapsed alveolar units reopening through pulmonary recruitment maneuvers. In his editorial "Open up the lung and keep the lung open", ${ }^{48}$ he recommends to actively reaerate alveolar units and keeping them open with sufficient PEEP levels, avoiding end-expiratory alveolar collapse, as well as promoting a ventilatory cycle with low differential pressures and promoting lung protection by preserving pulmonary surfactant. The purpose of treatment and acute respiratory failure prevention is based on 3 aspects: reopening of collapsed alveolar units, preserving surfactant active component in alveolar units that are still functional and preventing end-expiratory alveolar collapse.

Meade et al. ${ }^{49}$ carried out a multi-center study; they observed the benefit of protective mechanical ventilation after an alveolar recruitment maneuver. The results showed that patients with pulmonary opening had less resistant hypoxemia, lower hypoxemia-related mortality and less use of rescue therapies. However, no significant differences were observed in mortality. Recently, Amato ${ }^{50}$ showed in a comparative study of patients with cardiovascular surgery that those receiving a complete or aggressive recruitment maneuver had less mortality, postoperative complications and hypoxemia than patients receiving a less aggressive dose of pulmonary recruitment.

Alveolar collapse is a consequence of the inflammatory process promoted by alveolar permeability with infiltrate of protein-rich fluid into the alveolar lumen, which inactivates pulmonary surfactant and promotes changes in alveolar surface tension that finally result in collapse. In addition to alterations of the surfactant system, there is overlapped pressure that promotes collapse mainly in posterior zones. The result of alveolar units' collapse is the loss io intra-alveolar volume: as collapsed alveolar units are added, residual functional capacity is decreased, which promotes atelectasis zones and the appearance of right-to-left intrapulmonary shunts with the resulting hypoxemia. In the syndrome original description, ${ }^{1}$ the authors recommend the use of PEEP to keep alveolar units open and avoid their collapse.

In spite of PEEP physiological effect, controlled clinical trials have failed to demonstrate an effect of protection and mortality decrease. In 1998, Amato et al. ${ }^{45}$ demonstrated in their study that high PEEP levels associated with low tidal volumes after a recruitment maneuver and low differential pressures are associated with higher oxygenation and lower mortality. The ARDS Network carried out a comparative study between two groups with different PEEP levels where no significant differences were observed between groups with regard to mortality. ${ }^{51}$ In 2008, Mercat et al..$^{52}$ performed a study where they compared two groups with acute respiratory distress: the patients who received pulmonary recruitment measures required lower vascular volume and a lower number of rescue maneuvers (prone position, nitric oxide, among others); patients who received high PEEP levels had less days 
Table 2. Clinical studies where the benefit of lung-protective measures was compared with standard therapy

\begin{tabular}{|c|c|c|c|c|c|c|c|c|c|c|}
\hline \multirow[t]{2}{*}{ Study (reference) } & \multicolumn{2}{|c|}{ No. of patients } & \multicolumn{2}{|c|}{$\begin{array}{c}\text { Measured TV mean } \\
(\mathrm{mL} / \mathrm{kg})\end{array}$} & \multicolumn{2}{|c|}{$\begin{array}{l}\text { Mean plateau pressure } \\
\left(\mathrm{cm} \mathrm{H} \mathrm{H}_{2} \mathrm{O}\right)\end{array}$} & \multicolumn{2}{|c|}{$\begin{array}{c}\text { Mean PEEP } \\
\left(\mathrm{cm} \mathrm{H}_{2} \mathrm{O}\right)\end{array}$} & \multicolumn{2}{|c|}{$\begin{array}{l}\text { Mortality } \\
(\%)\end{array}$} \\
\hline & Exp. & Control & Exp. & Control & Exp. & Control & Exp. & Control & Exp. & Control \\
\hline Brochard 42 & 58 & 58 & 7.1 & 10.3 & 25.7 & 31.7 & 9.6 & 8.5 & 46.6 & 37.9 \\
\hline Stewart ${ }^{43}$ & 60 & 60 & 7.2 & 10.8 & 22.3 & 26.8 & 8.6 & 7.2 & 50 & 47 \\
\hline Brower ${ }^{44}$ & 26 & 26 & 7.3 & 10.2 & 24.9 & 30.6 & NA & NA & 50 & 46 \\
\hline Amato 45 & 29 & 24 & 6.1 & 11.6 & 23.7 & 37.8 & 13.2 & 9.3 & 38 & 71 \\
\hline ARDS Network ${ }^{46}$ & 432 & 429 & 6.2 & 11.8 & 25 & 36 & 8.1 & 9.1 & 31 & 39.8 \\
\hline
\end{tabular}

on mechanical ventilation and fewer days of organ dysfunction.

Briel et al..$^{53}$ conducted a meta-analysis regarding the use of PEEP levels comparing groups that received high PEEP versus low PEEP with a tidal volume of $6 \mathrm{~mL} / \mathrm{kg}$. The authors reported that patients with high PEEP had higher plateau pressures than patients with low PEEP, lower $\mathrm{FiO}_{2}$ levels and better oxygenation. They also documented higher survival at the moment of hospitalization (60 days) in patients with acute respiratory distress who randomly received high PEEP levels. In addition, they documented that patients with respiratory distress at day 28 had more days without ventilatory support than patients with low PEEP levels.

Amato et al. ${ }^{21}$ carried out a study to determine the effect of differential pressure in patients with acute respiratory distress. The study included the results of patients who participated in respiratory distress trials. The authors established that hospital mortality is increased when patients exhibit a constant PEEP level with differential pressure increases characterized by high levels of plateau pressure; in patients with differential pressure constant levels and increases in PEEP level, no association was observed with mortality. Finally, decreased mortality was observed in patients in whom PEEP was increased and differential pressure was reduced. The authors established that, for each $7 \mathrm{~cm} \mathrm{H}_{2} \mathrm{O}$ above $15 \mathrm{~cm} \mathrm{H}_{2} \mathrm{O}$ in differential pressure, an increase in the risk of death was observed.

Recently, Guérin et al. ${ }^{54}$ carried out a post hoc study of patients with respiratory distress included in two randomized trials. The authors reported a significant association between differential pressure increase and mortality at day 1 .

High-frequency oscillatory ventilation (HFOV) is a ventilation mode that owing to its performance characteristics (very low tidal volumes, respiratory rates close to 600 per minute, high airway pressures and low differential pressures) adapts to the protective ventilation concept. Recently, two randomized clinical trials ${ }^{55,56}$ were reported where standard ventilation was compared against HFOV. In the multi-center OSCILLATE trial, Ferguson et al. showed that patients who received HFOV had higher mortality than those who received standard protective ventilation. In the second multi-center OSCAR trial, Young et al. ${ }^{56}$ demonstrated that patients who received HFOV showed no mortality differences as compared with subjects treated with standard protective ventilation. Recently, an expert consensus did not recommend the use of HFOV as initial therapeutic measure for the management of acute respiratory distress.

Guérin et al. ${ }^{18}$ carried out a clinical study with the purpose to determine the benefit of the use of the prone position in patients with acute respiratory distress. The study demonstrated that patients with severe hypoxemia who are placed in the prone position for more than 12 hours have better survival than patients in the supine position. The reported mortality is the lowest recorded in clinical trials.

\section{Rescue measures}

Over the course of 50 years, mortality from ARDS continues to be high. Reports in the literature range from 40 to $90 \%$, depending on the country, hospital and period mortality is detailed at. ${ }^{33}$ Hypoxemia and multiple organ failure are the main causes of death; therefore, "rescue" therapeutic measures should be implemented as soon as protective ventilation standard measures have failed in order to reestablish gas exchange and limit multiple organ damage. The purpose of these measures is to avoid hypoxemia-related death and progression to multiple organ dysfunction. 
HFOV continues to be valid as a rescue measure when standard ventilation has failed to maintain adequate gas exchange with parameters of lung protection.

In a comparative study, Mehta et al..$^{57}$ demonstrated that patients who received HFOV as a rescue measure had better survival than those who continued on standard ventilation. Although HFOV is not recommended as a therapeutic measure for ARDS initial treatment, it should be established when standard ventilation has failed. High frequency oscillatory ventilator performance enables providing ventilation with low tidal volumes at high airway pressures and low differential pressures, which is ideal for a lung with low distensibility. HFOV is a temporary therapeutic measure, and once the pulmonary function has been able to be stabilized at lower mean airway pressure, transition to standard ventilation should therefore be initiated.

Pulmonary function replacement extracorporeal membrane oxygenation (ECMO) is an advanced rescue measure to avoid hypoxemia-related death. The development and simplification of extracorporeal pumps to maintain adequate perfusion, as well as the development of better and more simplified gas exchange membranes and venous-venous access with high-safety catheters have enabled an improvement for a more efficient, practical and safe use of these devices. ${ }^{58}$ The new devices for providing ECMO have produced better results than first-generation devices.
The AH1N1 influenza pandemic gave the opportunity for these devices to be used as an advanced measure for the rescue of the pulmonary function in patients with severe pneumonia. ${ }^{58}$ Currently, there is a limited number of clinical trials that allow assessing the efficacy and safety of this therapeutic measure. Peek et al. ${ }^{59}$ carried out a clinical trial comparing the use of ECMO versus standard therapy in patients with severe ARDS. The CESAR trial, which included 180 patients, showed no differences in mortality. The use of ECMO should be started when the other measures have failed. However, late ECMO initiation may not yield the expected results.

Other types of extracorporeal membrane gas exchange are under investigation. Low-flow venous-venous $\mathrm{CO}_{2}$ exchangers allow, in theory, providing mechanical ventilation ultra-protective measures by enabling tidal volume administration at very low dose (lower than $4 \mathrm{~mL} / \mathrm{kg}$ ) and at very low peak pressures. Clinical study on the use of this measure is underway. ${ }^{60,61}$

\section{Conclusion}

At 50 years of ARDS description, mortality from this syndrome continues to be high. Treatment is focused on limiting and decreasing the inflammatory process, pulmonary edema and mechanical ventilation-induced injury by means of protective measures during mechanical ventilation. 


\title{
Acute respiratory distress syndrome pathophysiology
}

\author{
Jesús-Carlos Briones-Garduño
}

Acute respiratory distress syndrome pathophysiology implies a rupture of the alveolar-capillary barrier, resulting from complex interactions between activated cells, humoral response and cell mediators. After initial injury (e.g., endotoxemia), pro-inflammatory cells are activated with synthesis and secretion of inflammatory mediators, as well as polymorphonuclear cell accumulation, i.e. phagocytic cells that are part of the body's first line of defense and are normally found in blood circulation, but when an infectious-inflammatory process occurs, migrate to the site of injury by means of chemotaxis via interleukin (IL-8). By means of specific receptors, these cells recognize opsonized and non-opsonized microorganisms to facilitate their capture, causing phagocytosed microorganism death by the action of oxygen free radicals (anion superoxide, hydroxyl radicals, and hydrogen peroxide, produced by the NADPH oxidase enzymatic complex) or nitrogen free radicals (nitric oxide), as well as other molecules such as myeloperoxidase.

It should be noted that these cells progressively release preformed substances contained in their granules (lipocalin, lysozyme, LL-37 and others such as metalloproteinases MP8, MMP9 and MMP25), which induce the formation of neutrophil extracellular traps (NET), described in 2004 by Brinkman, which act as a physical barrier to prevent dissemination and tissue damage, regulating different infections, as well as limiting the inflammatory process, which activates the complement cascade, eliciting the release of arachidonic metabolites, cytokines (IL-1, IL-6, IL-10, TNF $\alpha$ ), proteolytic enzymes and oxygen free radicals; simultaneously, inflammatory response is magnified, with activation of monocytes, alveolar macrophages and platelets with increased adhesiveness and aggregability, thus causing vascular microthrombosis and local and systemic secondary ischemia, which explains multiple organ failure occurring in many cases (Figs. 5 and 6). ${ }^{62-64}$

Lungs that are injured by this mechanism require mechanical ventilation support, which can contribute to injury by 4 additional processes:

- Barotrauma (injury caused by high pressures or extra-alveolar air).

- Volutrauma (injury due to transpulmonary high pressures and over-distension).
- Atelectrauma (collapse of unstable alveoli secondary to cyclic open/closure with stretching of healthy regions).

- Biotrauma (due to humoral alteration).

Mechanical ventilator physical forces alter the pulmonary structure and elasticity, since in injured lungs the inflation pattern is heterogeneous and alveolar distension force can reach up to $140 \mathrm{~cm} \mathrm{H}_{2} \mathrm{O}$, even with transpulmonary pressures of $30 \mathrm{~cm} \mathrm{H}_{2} \mathrm{O}$, thus eliciting cyclic injury by shear forces resulting from repetitive collapse and over-distension that favor mediators, endotoxins and bacteria translocation from the lung to systemic circulation. ${ }^{65}$

In ARDS clinical-pathological evolution, three phases are classically recognized:

- Exudative phase: There is rupture of the alveolus-capillary membrane, with the resulting accumulation of protein and cytokine-rich alveolar edema. The exudative phase lasts approximately 7 days and is clinically characterized by dyspnea, tachypnea and severe hypoxemia.

- Proliferative phase: If there is no recovery, some patients will progressively develop lung injury and present with evidence of pulmonary interstitial inflammation and fibrosis. This phase lasts between 7 and 21 days.

- Fibrotic phase: Although the majority of patients recover 3 to 4 weeks after initial injury, some experience progressive fibrosis and thus require prolonged ventilatory support, which predisposes them to the complications observed in intensive care units. Several studies support the theory that this ARDS final phase is caused by the use of mechanical ventilation with elevated volume or pressure.

Normal alveolar-capillary structure provides a large surface of gas exchange and a narrow barrier between alveolar gas and lung capillary blood. Diffuse damage of the alveolar region occurs during the acute or exudative phase of ARDS lung injury. This damage involves endothelial and epithelial tissue and disrupts the pulmonary barrier, flooding the alveolar spaces with fluid, which inactivates the surfactant, causing inflammation and producing alterations in gas exchange. These events are reflected by the presence of bilateral 


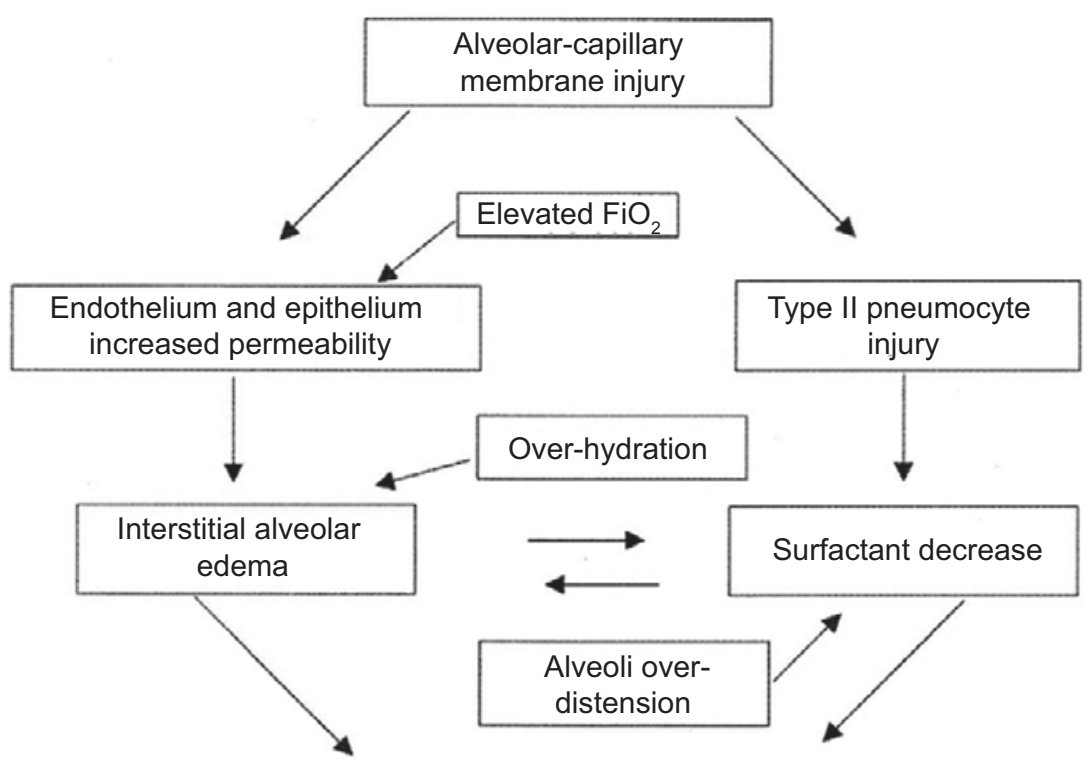

Filling or closure of alveoli and respiratory airway or both

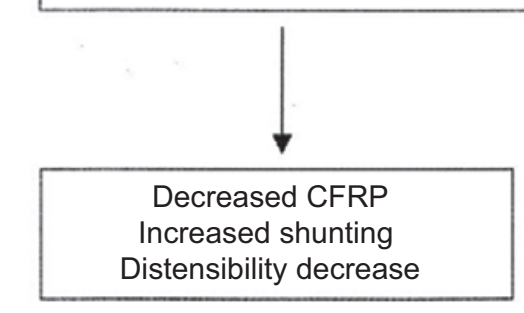

Figure 5. ARDS pathophysiology.

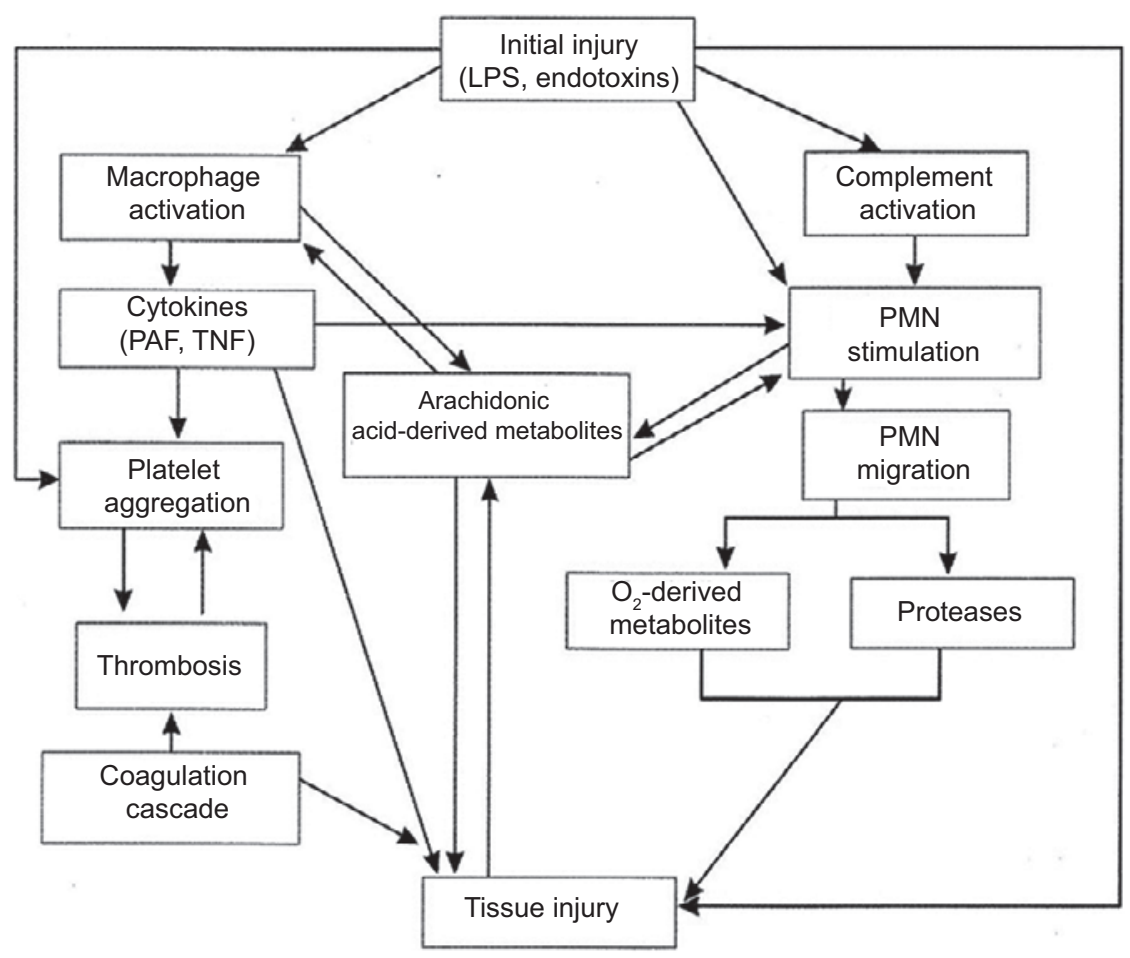

Figure 6. Mechanism of tissue injury. 
infiltrates, which are indistinguishable from those of cardiogenic origin by conventional radiology.

Pathologic findings comprise diffuse alveolar damage, including capillary injury. Alveolar spaces show hyaline membranes and are filled with protein and inflammatory cell-rich edema. Interstitial space, alveoli, small vessels and capillaries contain macrophages, neutrophils and erythrocytes as well. The acute phase can resolve or progress to fibrosis with persistent hypoxemia, dead space increase, pulmonary hypertension and distensibility loss. Chest radiographs show new linear opacities consistent with ongoing fibrosis. Lung pathology examination shows fibrosis with collagen deposit, chronic and acute inflammation and edema incomplete resolution. The recovery phase is characterized by hypoxemia resolution and dead space and pulmonary distensibility improvement. Radiological anomalies generally do resolve; however microscopic fibrosis continues. ${ }^{66}$ 


\title{
Kidney-lung interaction
}

\author{
Manuel Antonio Díaz de León-Ponce
}

Doctors Buford and Burbank found, in soldiers who died during World War I, pulmonary tissue edema, which they called "traumatic wet lung". In 1948, Moon described hyperemia, edema, hemorrhage and atelectasis in the lungs of dead soldiers, the cause of which he attributed to endothelial injury. Two years later, Jenkins reported atelectasis and pulmonary congestion that he considered to be due to over-hydration in the resuscitation of patients in state of hypovolemic shock (Figure 7). , $67,68^{\circ}$

Ashbaugh, who is commemorated in this symposium, described the acute respiratory distress syndrome (ARDS) five decades ago; he specified that its diagnosis is confirmed by clinical, laboratory and imaging data, and classified it in 4 stages (Figure 8). ${ }^{1}$

Seven years later, the first study confirming Ashbaugh's data was published in Mexico, but the stages were shown not to depend on time, but on injury severity and histological factors (Figure 9). ${ }^{69}$ However, five decades ago, the three great syndromes that cause critical patients' death of were not known.

- Systemic inflammatory response syndrome (SIRS).

- SIRS-induced immune response syndrome.

- Multiple organ dysfunction syndrome

Seriously-ill patient mortality and morbidity depend on ARDS severity, on the immune capacity of the host and on patient adaptability and organic conditions. ${ }^{73}$

Apparently, the effect of kidney and lung injury doesn't explain the above; since 4 decades ago, we know that this depends on patient immune response, on ARDS and on the damage to organs such as the heart, spleen, brain, liver and intestine, a conjunction known as MODS (Figure 10). In the above, the capacity of each human being in the presence of inflammatory response, the capacity of each organ in the presence of injury and early treatment instauration do intervene. ${ }^{68,73}$

In 2009, Risso et al. ${ }^{74}$ described that the lung-kidney syndrome was due to diffuse alveolar hemorrhage and glomerulonephritis, associated it with vasculitis and collagenopathies, and indicated that establishing an early diagnosis and starting aggressive treatment with

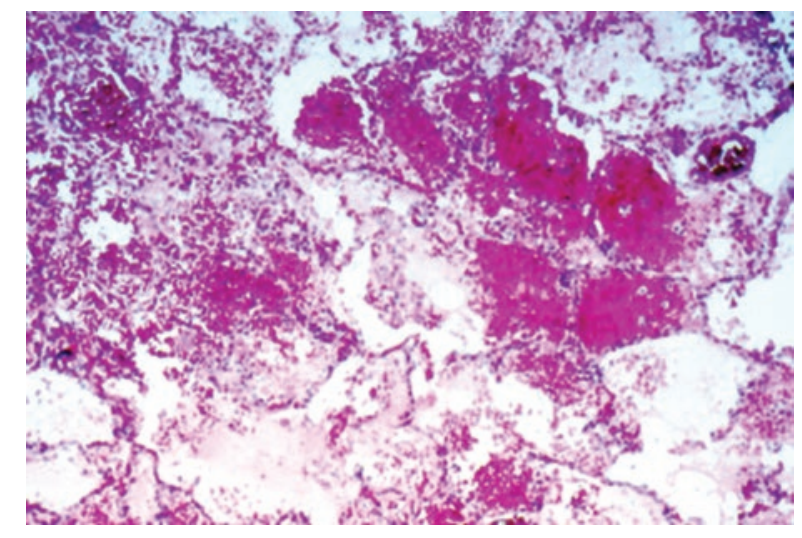

Figure 7. Image where alveolar edema and hemorrhage are observed.

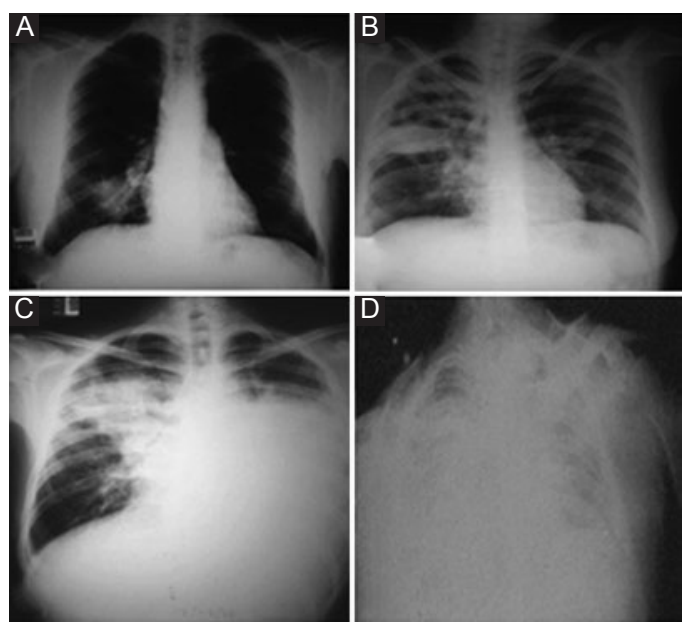

Figure 8. Adult respiratory distress syndrome evolutionary stages.

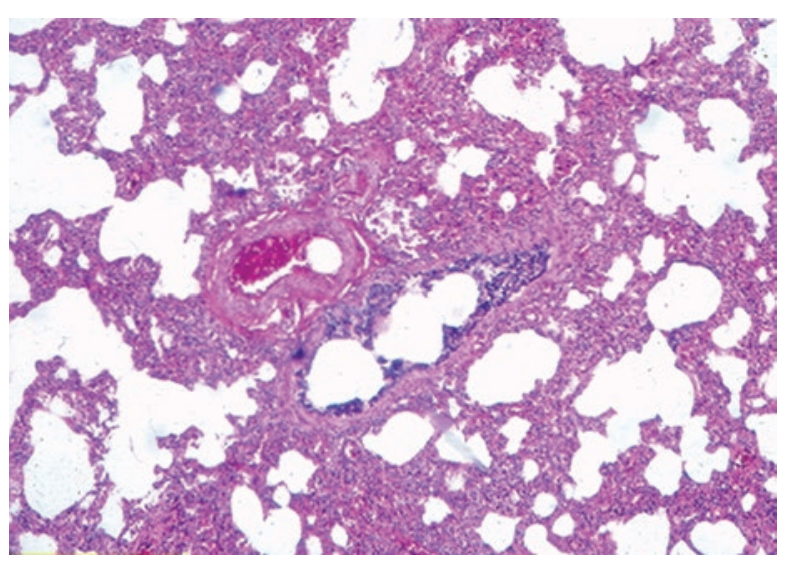

Figure 9. Pulmonary biopsy showing diffuse alveolar damage. 


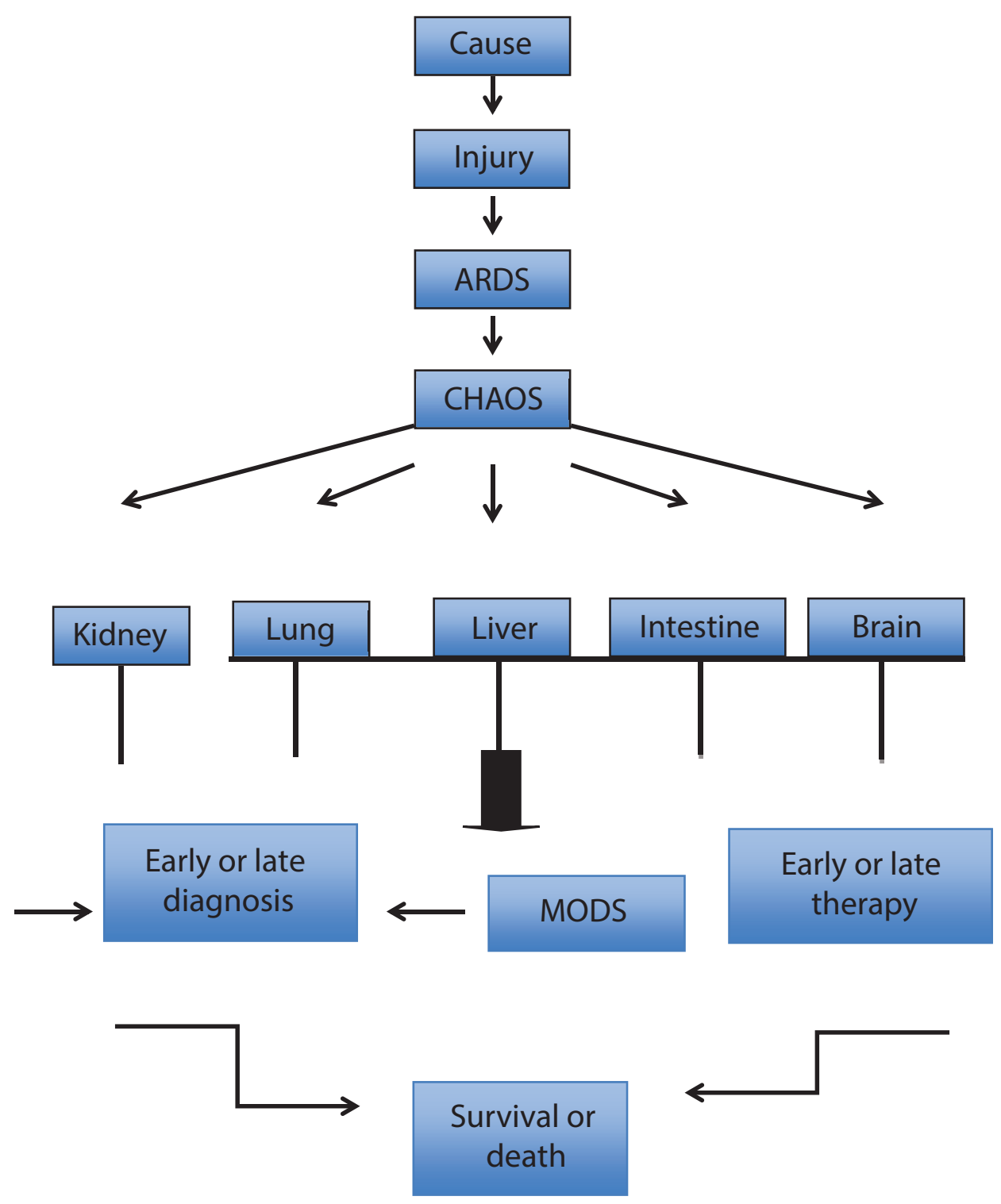

Figure 10. Multiple organ dysfunction pathophysiology. SIRS, systemic inflammatory response syndrome; CRSRS, counter-regulatory systemic response syndrome; MODS, multiple organ dysfunction syndrome.

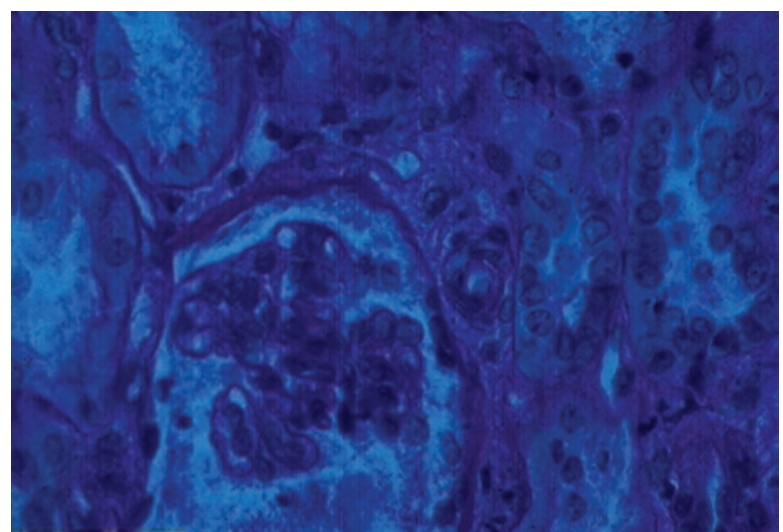

Figure 11. Renal biopsy of a patient with sepsis, where glomerulonephritis is observed. high-dose corticoids, immunosuppressants, tumor necrosis inhibitors and plasmapheresis is necessary (which had already been published in $1975^{75}$ ) (Figure 11), in order to evade the immune response of all antibodies of disease itself or of different inflammation mediators. Studies from 2011, 2012 and a 2017 review by the Domenech et al. group try to confirm the above. ${ }^{76-79}$

In 1980, we published as a therapeutic novelty the early use of extracorporeal dialysis and exchange transfusion with oxygen bubbling,,$^{80}$ which is a precedent of the procedure mentioned by Russo et al. (plasmapheresis and membrane oxygenator) (Figure 12). 


\section{HEMODIALYSIS, EXCHANGE TRANSFUSION AND OXYGENATION}

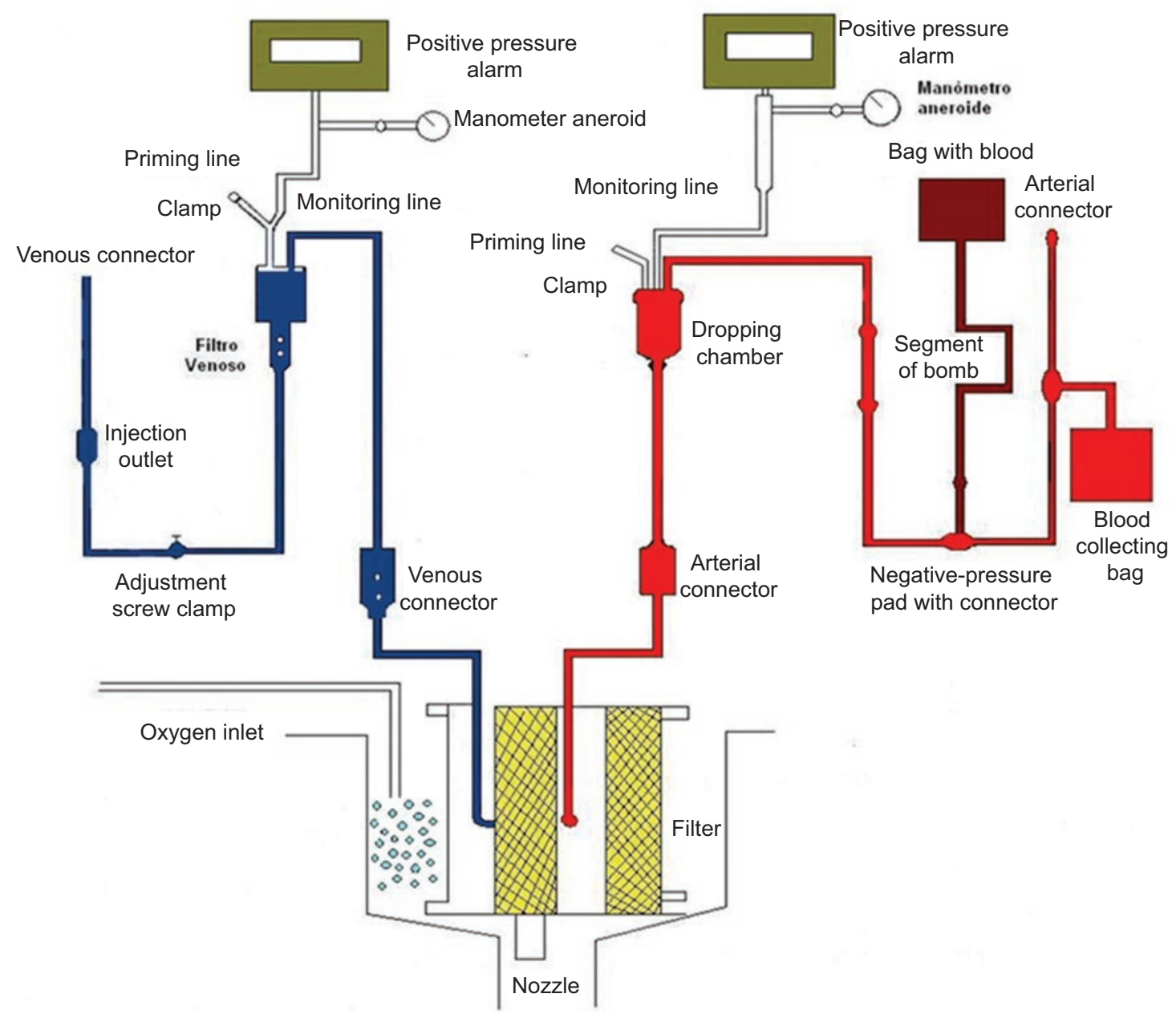

Figure 12. Diagram showing the hemodialysis with oxygenation technique.con oxigenación.

\section{References}

1. Ashbaugh DG, Bigelow BD, Petty TL, Levine BE. Acute respiratory distress in adults. Lancet. 1967;2(7511):319-323.

2. Bellani G, Laffey JG, Pham T, Fan E, Brochard L, Esteban A, et al. Epidemiology, patterns of care, mortality for patients with acute respiratory distress syndrome in intensive care units in 50 countries. JAMA. 2016;315(8):788-800.

3. Villar J, Blanco J, Kacmarek RM. Current incidence and outcome of the respiratory distress syndrome. Curr Opin Crit Care. 2016;22(1):1-6.

4. Murray JF, Matthay MA, Luce JM, Flick MR. An expanded definition of the adult respiratory distress syndrome. Am Rev Respir Dis. 1988; 138(3):720-723

5. Bernard GR, Artigas A, Brigham KL, Carlet J, Falke K, Hudson L, et al. The American-European Consensus Conference on ARDS. Definition, mechanisms, relevant outcomes, and clinical trials coordination. Am J Respir Crit Care Med. 1994;149(3 Pt 1):818-824.

6. ARDS Definition Task Force; Ranieri VM, Rubenfield GD, Thompson BT, Ferguson ND, Caldwell E, et al. Acute respiratory distress syndrome: The Berlin Definition. JAMA. 2012;307(23):2526-2533.

7. Han S, Mallampalli RK. The acute respiratory distress syndrome: from mechanism to translation. J Immunol. 2015;194(3):855-860.

8. Binnie A, Tsang JL, Dos-Santos CC. Biomarkers in acute respiratory distress syndrome. Curr Opin Crit Care. 2014;20(1):47-55.

9. Gattinoni L, Marini JJ, Pesenti A, Quientel M, Mancebo J, Brochard L. The "baby lung" became adult. Intensive Care Med. 2016; 42(5): 663-673.
10. Kallet $\mathrm{RH}$. A comprehensive review of prone position in ARDS. Respir Care. 2015;60(11):1660-1687.

11. Brower RG, Matthay MA, Morris A, Schoenfeld D, Thompson BT, Wheeler A, et al. Ventilation with lower tidal volumes as compared with traditional tidal volumes for acute lung injury and the acute respiratory distress syndrome. N Engl J Med. 2000;342(18):1301-1308.

12. Malhorta A. Low-tidal-volume ventilation in the acute respiratory distress syndrome. N Engl J Med. 2007;357(11):1113-1120.

13. Matthay MA, Ware LB, Zimmerman GA. The acute respiratory distress syndrome. J Clin Invest. 2012;122(8):2731-2740.

14. Gonzales JN, Lucas R, Verin AD. The acute respiratory distress syndrome: mechanisms and perspective therapeutic approaches. Austin $J$ Vasc Med. 2015;2(1):1009-1016.

15. Gattinoni L, Tonetti T, Cressoni M, Cadringher P, Hermann P, Moerer O, et al. Ventilator-related causes of lung injury: the mechanical power. Intensive Care Med. 2016;42(10):1567-1575.

16. Beitler JR, Malhorta A, Thompson BT. Ventilator-induced lung injury. Clin Chest Med. 2016;37(4):633-646.

17. Gattinoni L, Marini JJ, Collino F, Maiolo G, Rapetti F, Tonetti T, et al. The future of mechanical ventilation: lessons from de present and the past. Crit Care. 2017;21:183-194.

18. Guérin C, Reignier J, Richard JC, Beuret $P$, Gacounin $A$, Boulain $T$, et al Prone positioning in severe acute respiratory distress syndrome. $\mathrm{N}$ Engl J Med. 2013;368(23):2159-2168.

19. Brodie D, Bacchetta M. Extracorporeal membrane oxygenation for ARDS in adults. N Engl J Med. 2011;365(20):1905-1914.

20. Rozé H, Repusseau B, Ouattara A. Extracorporeal membrane oxygenation in adults for severe acute respiratory failure. Ann Fr Anesth Reanim. 2014;33(7-8):492-494. 
21. Amato MBP, Meade MO, Slutsky AS, Brochard L, Costa EL, Schoenfeld DA, et al. Driving pressure and survival in the acute respiratory distress syndrome. N Engl J Med. 2015;372:747-755.

22. Nieman GF, Satalin J, Andrews P, Aiash H, Habashi NM, Gatto LA Personalizing mechanical ventilation according to physiologic parameters to stabilize alveoli and minimize ventilator induced lung injury (VILI). Intensive Care Med Exp. 2017;5:8-28.

23. Papazian L, Forel JM, Gacounin A, Penot-Ragon C, Perrin G, Loundou A et al. Neuromuscular blockers in early acute respiratory distress syndrome. N Engl J Med. 2010;363(12):1107-1116.

24. Toner P, McAuley DF, Shyamsundar M. Aspirin as a potential treatment in sepsis or acute respiratory distress syndrome. Crit Care. 2015;19:374-380

25. Rojas M, Xu J, Woods CR, Mora AL, Spears W, Roman J, et al. Bone marrow-derived mesenchymal stem cells in repair of the injured lung. Am J Respir Cell Mol Biol. 2005;33(2):145-152.

26. Duggal A, Ganapathy A, Ratnapalan M, Adhikari NK. Pharmacological treatments for acute respiratory distress syndrome: systematic review. Minerva Anestesiol. 2015;81(5):567-588.

27. Zhang Z, Chen $\mathrm{L}, \mathrm{Ni} \mathrm{H}$. The effectiveness of corticosteroids on mortality in patients with acute respiratory distress syndrome or acute lung injury: a secondary analysis. Sci Rep. 2015;5:17654.

28. Attaway $\mathrm{AH}$, Myers $\mathrm{C}$, Velani S, Schilz R. Inhaled prostacyclin as a salvage therapy for ARDS: Can we find the right patient? Respir Care. 2017:62(8):1113-1115.

29. Gattinoni L, Cressoni M, Brazzi L. Fluids in ARDS: from onset through recovery. Curr Opin Crit Care. 2014;20(4):373-377.

30. Valente-Barbas C, Janot-Matos GF, Passos-Amato M Ribeiro-Carvalho CR. Goal-oriented respiratory management for critically ill patients with acute respiratory distress syndrome. Crit Care Res Pract. 2012;2012:952-965

31. Herridge MS, Moss M, Hough CL, Hopkin RO, Rice TW, Bienvenue OJ et al. Recovery and outcomes after the acute respiratory distress syndrome (ARDS) in patients and their family caregivers. Intensive Care Med. 2016;42(5):725-738.

32. Ware L, Matthay MA. The acute respiratory distress syndrome. N Engl J Med. 2000;342(18):1334-1349

33. Máca J, Jor O, Holub M, Sklienka P, Burša F, Burda M, et al. Past and present ARDS mortality rates: a systematic review. Respir Care. 2017; 62(1):113-122.

34. Fan E, Del Sorbo L, Goligher EC, Hodgson CL, Munshi L, Walkey A, et al. An Official American Thoracic Society/European Society of Intensive Care Medicine/Society of Critical Care Medicine Clinical Practice Guideline: mechanical ventilation in adult patients with acute respiratory distress syndrome. Am J Respir Crit Care Med. 2017;195(9):1253-1263.

35. Rhodes A, Evans L, Alhazzani W, Levy MM, Antonelli M, Ferrer R, et al. Surviving sepsis campaign: International Guidelines for Management of Sepsis and Septic Shock: 2016. Crit Care Med. 2017;45(3):486-552.

36. Slutsky AS, Raniery VM. Ventilator-induced lung injury. N Engl J Med. 2014:369(22):2126-2136.

37. Meduri GU, Bridges L, Shih MC, Marik PE, Siemieniuk RA, Kocak M. Prolonged glucocorticoid treatment is associated with improved ARDS outcomes: analysis of individual patients' data from four randomized trials and trial-level meta-analysis of the updated literature. Intensive Care Med. 2016;42(5):829-840.

38. Adhikari NK, Dellinger RP, Lundin S, Payen D, Vallet B, Gerlach H, et al. Inhaled nitric oxide does not reduce mortality in patients with acute respiratory distress syndrome regardless of severity: systematic review and meta-analysis. Crit Care Med. 2014;42(2): 404-412.

39. Sakr Y, Vincent JL, Reinhart K, Groeneveld J, Michalopoulos A Sprung $C L$, et al. High tidal volume and positive fluid balance are associated with worse outcome in acute lung injury. Chest. 2005;128(5):3098-3108

40. Martin GS, Moss M, Wheeler AP, Mealer M, Morris JA, Bernard GR A randomized, controlled trial of furosemide with or without albumin in hypoproteinemic patients with acute lung injury. Crit Care Med. 2005:33(8):1681-1687.

41. National Heart, Lung, and Blood Institute Acute Respiratory Distress Syndrome (ARDS) Clinical Trials Network; Wiedemann HP, Wheeler AP, Bernard GR, Thompson BT, Hayden D, deBoisblanc B, et al. Comparison of two fluid-management strategies in acute lung injury. $\mathrm{N}$ Engl $\mathrm{J}$ Med. 2006;354(24):2564-2575.

42. Brochard L, Roudot-Thoraval F, Roupie E, Delclaux C, Chastre J, Fernández-Mondéjar $\mathrm{E}$, et al. Tidal volume reduction for prevention of ventilator-induced lung injury in acute respiratory distress syndrome. The Multicenter Trail Group on Tidal Volume reduction in ARDS. Am J Respir Crit Care Med. 1998:158(6):1831-1838.

43. Stewart TE, Meade MO, Cook DJ, Granton JT, Hodder RV, Lapinsky SE et al. Evaluation of a ventilation strategy to prevent barotrauma in patients at high risk for acute respiratory distress syndrome. N Engl J Med. 1998;338(6):355-361.

44. Brower RG, Shanholtz CB, Fessler HE, Shade DM, White P, Wiener CM, et al. Prospective, randomized, controlled clinical trial comparing tra- ditional versus reduced tidal volume ventilation in acute respiratory distress syndrome patients. Crit Care Med. 1999;27(8):1492-1498.

45. Passos-Amato MB, Valente-Barbas CS, Machado-Medeiros DM, Borges-Magaldi R, Schettino GP, Lorenzi-Filho G, et al. Effect of a protective-ventilation strategy on mortality in the acute respiratory distress syndrome. N Engl J Med. 1998;338:347-354.

46. The Acute Respiratory Distress Syndrome Network. Ventilation with lower tidal volumes as compared with traditional tidal volumes for acute lung injury and the acute respiratory distress syndrome. $\mathrm{N}$ Engl $\mathrm{J}$ Med. 2000;342:1301-1308.

47. Burns KE, Adhikari NK, Slutsky AS, Guyatt GH, Villar J, Zhang H, et al Pressure and volume limited ventilation for the ventilatory management of patients with acute lung injury: a systematic review and meta-analysis. PLos One. 2011;6(1):e14623.

48. Lachmann B. Open up the lung and keep the lung open. Intensive Care Med. 1992;18(6):319-321.

49. Meade MO, Cook DJ, Guyatt GH, Slutsky AS, Arabi YM, Cooper DJ, et al. Ventilation strategy using low tidal volumes, recruitment maneuvers, and high positive end-expiratory pressure for acute lung injury and acute respiratory distress syndrome: a randomized controlled trial. JAMA. 2008;299(6):637-645.

50. Costa-Leme A, HaijarLA, Volpe MS, Fukushima JT, De-Santis-Santiago RR, Osawa $\mathrm{E}$, et al. Effect of intensive vs moderate alveolar recruitment strategies added to lung-protective ventilation on postoperative pulmonary complications a randomized clinical trial. JAMA. 2017; 317(14):1422-1432

51. Brower RG, Lanken PN, Maclntyre N, Matthay MA, Morris A, Ancukiewicz $\mathrm{M}$, et al. Higher versus lower positive end-expiratory pressures in patients with the acute respiratory distress syndrome. $\mathrm{N} \mathrm{Engl} \mathrm{J}$ Med. 2004;351(4):327-336

52. Mercat A, Richard JC, Vielle B, Jaber S, Osman D, Diehl JL, et al. Positive end-expiratory pressure setting in adults with acute lung injury and acute respiratory distress syndrome: a randomized controlled trial. JAMA. 2008;299(6):646-655.

53. Briel M, Meade M, Mercat A, Brower RG, Talmor D, Walter SD, et al. Higher vs lower positive end-expiratory pressure in patients with acute lung injury and acute respiratory distress syndrome: systematic review and meta-analysis. JAMA. 2010;303(9):865-873.

54. Guérin C, Papazian L, Reignier J, Ayzac L, Loundou A, Forel JM, et al. Effect of driving pressure on mortality in ARDS patients during lung protective mechanical ventilation in two randomized controlled trials. Critical Care. 2016;20:384

55. Ferguson ND, Cook DJ, Guyatt GH, Mehta S, Hand L, Austin P, et al. High-frequency oscillation in early acute respiratory distress syndrome. N Engl J Med. 2013;368(9):795-805.

56. Young D, Lamb SE, Shah S, MacKenzie I, Tunnicliffe W, Lall R, et al. High-frequency oscillation for acute respiratory distress syndrome. N Engl J Med 2013;368:806-813.

57. Chan KP, Stewart TE, Mehta S. High-frequency oscillatory ventilation for adult patients with ARDS. Chest. 2007:131(6):1907-1916.

58. Cooper DJ, Hodgson CL. Extracorporeal membrane oxygenation rescue for $\mathrm{H} 1 \mathrm{~N} 1$ acute respiratory distress syndrome: equipoise regained. Am J Respir Crit Care Med. 2013;187(3):224-226.

59. Peek GJ, Mugford M, Tiruvoipati R, Wilson A, Allen E, Thalanany MM, et al. Efficacy and economic assessment of conventional ventilatory support versus extracorporeal membrane oxygenation for severe adult respiratory failure (CESAR): a multicentre randomised controlled trial. Lancet. 2009;374(9698):1351-1363

60. Terragni PP, Del-Sorbo L, Mascia L, Urbino R, Martin EL, Birocco A et al. Tidal volume lower than $6 \mathrm{~mL} / \mathrm{kg}$ enhances lung protection: role of extracorporeal carbon dioxide removal. Anesthesiology. 2009;111(4):8.

61. Bein T, Weber-Carstens S, Goldmann A, Müller T, Staudinger T, Brederlau J, et al. Lower tidal volume strategy $(\approx 3 \mathrm{~mL} / \mathrm{kg})$ combined with extracorporeal $\mathrm{CO} 2$ removal versus 'conventional' protective ventilation $(6 \mathrm{~mL} / \mathrm{kg})$ in severe ARDS: the prospective randomized Xtravent-study. Intensive Care Med. 2013;39(5):847-856.

62. Fujishima S. Pathophysiology and biomarkers of acute respiratory distress syndrome. J Intensive Care. 2004;2(1):32

63. Frantzeskaki F, Armaganidis A, Orfanos SE. Immunothrombosis in acute respiratory distress syndrome: cross talks between inflamation and coagulation. Respiration. 2017;93(3):212-225.

64. Yam-Puc JC, García-Marín LG, Sánchez-Torres LE. Trampas extracelulares de neutrófilos (NET), consecuencia de un suicidio celular. Gac Med Mex. 2012;148:68-75

65. Díaz-Carrillo MA. Biología molecular de la ventilación mecánica. Rev Mex Anest. 2015;38(s1):s220-s222.

66. Díaz de León PM, Moreno SAA, González DJl, Briones GJC. Actualidades del síndrome de insuficiencia respiratoria aguda. Rev Asoc Mex Med Crit Ter Int. 2007;21(4):217-222.

67. Díaz de León-Ponce $M$, Mujica-Hernández $M$, Olvera-Chávez A González-Díaz JI, Montealegre-Ramírez PA, Moreno-Santillán A, et al. Síndrome de insuficiencia respiratoria aguda (SIRA). Rev Asoc Mex Med Crit Ter Int. 2004;18(1):24-33. 
68. Díaz de León-Ponce M, Moreno-Santillán A, González-Díaz JI, Briones-Garduño JC. Actualidades del síndrome de insuficiencia respiratoria aguda. Rev Asoc Mex Med Crit Ter Int. 2007;21(4):217-222.

69. Díaz de León-Ponce M, Terán EH, Ramírez OJ. Pulmón de choque en gineco-obstetricia. Ginec Obstet Mex. 1975;37:197-206.

70. Tilney NL, Barley GL, Morgan AP. Sequential system failure after rupture of abdominal aortic aneurysms. An unsolved problem in postoperative care. Ann Surg. 1973;178(2):117-122.

71. Rangel-Frausto MS, Pittet D, Costigan M, Hwang T, Davis CS, Wenzel RP. The natural history of the systemic inflammatory response syndrome. A prospective study. JAMA. 1995;273(2):117-123.

72. Feregrino GM, Díaz de León-Ponce M. Inmunología en el estado crítico. En: Díaz de León-Ponce M. Medicina crítica. México: Prado; 1990.

73. Carrillo ER. Sepsis. México: Alfil; 2009.

74. Risso JA, Mazzocchi O, De-All J, Gnocchi CA. Síndrome pulmón-riñón. Medicina (B. Aires). 2009;69(6):663-673.
75. Díaz de León-Ponce $\mathrm{M}$, Exaire $\mathrm{ME}$, Pizzuto $\mathrm{CH}$. Glomerulonefritis rápidamente progresiva tratada con anticoagulantes y antitrombóticos. Bol Med IMSS. 1975;1:49-54.

76. Doi K, Fujita T, Noiri E, Ishizu T. Lung injury following acute kidney injury: kidney-lung crosstalk. Clin Exp Nephol. 2011;15(4):464-470.

77. Izaguirre A, Herrando S, Daborro M, Bauni C. Síndrome pulmón-riñón. Rev Hosp Ital B Aires. 2012;32(3):1-3.

78. Faubel S, Edelstein CL. Mechanisms and mediators of lung injury after acute kidney injury. Nat Rev Nephrol. 2016;12(1):48-60.

79. Domenech P, Pérez T, Saldarini A, Uad P, Musso CG. Kidney-lung pathophysiological crosstalk: its characteristics and importance. Int Urol Nephrol. 2017;49(7):1211-1215.

80. Díaz de León-Ponce M, Foubert DC, Díaz MT, López FP, Ramírez HL, Martínez GM. Hemodiálisis-exanguinotransfusión y oxigenación en choque séptico. Un nuevo procedimiento. Nefrologia Mex. 1980; $1: 37-42$. 